\title{
THE EFFECT OF KNOWLEDGE MANAGEMENT AND HUMAN RESOURCE DEVELOPMENT ON EMPLOYEE PERFORMANCE AT PT. SKY PACIFIC INDONESIA
}

\author{
Firmansyah W.R. Dani, Suryanto, Muhyi Herwan Abdul \\ Department of Business Administration, University of Padjadjaran, Bandung, Indonesia \\ *E-mail: dnwiradimadja@gmail.com \\ ORCID: 0000-0002-5527-1399
}

\begin{abstract}
The most important asset in a business company to be able to compete in the long term is its human resources. Knowledge possessed by each individual in a company is a key factor so that the company can be superior to its competitors. Knowledge possessed by each employee can improve the performance and image of a company in the eyes of consumers. The object of this research is PT. Sky Pacific Indonesia. PT. Sky Pacific Indonesia is a business company that provides environmental testing laboratory services, established in Bogor Indonesia in 2009. The business sector of the company is highly dependent and relies on the competence and knowledge of its human resources. The purpose of this study was to determine how much knowledge management and human resource development affect the performance of PT. Sky Pacific Indonesia. 62 respondents were used as the samples of this study, the research data was primary data taken from questionnaires and company data. The data obtained from the questionnaires were then processed using a quantitative method with path analysis technique. Research shows a positive and significant influence between variables. The results showed that knowledge management affected $20.20 \%$ of employee performance, then the human resource development affected $36.38 \%$ of employee performance, and the effect of knowledge management and human resource development on performance was $41.42 \%$, this could be interpreted that knowledge management and the human resource development affects the level of company performance.
\end{abstract}

\section{KEY WORDS}

Knowledge, management, human resources, development, employee, performance.

Today's business world is moving very fast, this requires various business companies to keep abreast of developments, changes, and demands of their customers in order to become a superior company to their business competitors. To be a superior company, there must be some qualities possessed which are surpassing its competitors, one of the most important assets that a company must possess to exceed its competitors is knowledge.

Knowledge is the main capital of an organization to be able to always compete with its competitors and also as the main capital in the survival of an organization. The ability to gather, interpret, direct, and communicate knowledge is the most basic material in developing an innovative organization. Carol Stephenson President and CEO of Stentor Resource Centre Inc. also said "Knowledge, without a doubt, is the critical capital in any modern organization. The ability to collect, interpret, direct and communicate knowledge is fundamental to developing an innovative organization" (Manele Moses, 2005; 1). Without a doubt, knowledge is the most important capital in any modern organization, therefore we need a knowledge management in a company or organization to manage that knowledge. To improve performance, in addition to knowledge management, human resource development is also needed. The human resource development is conducted so that the process of knowledge transfer can be carried out well.

\section{LITERATURE REVIEW}

Before understanding knowledge management $(\mathrm{KM})$, it is important to first review what is called as knowledge. According to Alavi and Leidner (2001;107) knowledge is described 
as a state of mind where knowing and understanding is obtained through experience or learning. Notoatmodjo (2007; 139), interpreted knowledge as the result of knowing, and this occurs after people have sensed a particular object, sensing occurs in the human senses in the forms of the sense of sight, hearing, smell, taste, and touch. Most human knowledge is obtained through the eyes and ears. Knowledge, or cognitive knowledge, is a very important domain in shaping one's actions. Frappaolo and Wayne $(1997 ; 12)$ stated that knowledge is a piece of information located in the human mind which is useful for decision making even in different conditions. Kimiz Dalkir (2011: 9) in broad outline of knowledge in business, it can be divided into two types, Tacit Knowledge (Implicit) and Explicit knowledge:

Tacit Knowledge. Tacit knowledge is basically very personal and difficult to formalize, so it is difficult to be communicated to others, Nonaka \& Takeuchi $(1995 ; 8)$. Tacit Knowledge is stored in the minds of each person and is difficult to share. Tacit Knowledge is difficult to articulate, write, and describe in words.

Explicit Knowledge. Explicit Knowledge is the knowledge that can be expressed in words and numbers and can be easily communicated and shared in the form of complicated data, scientific formulas, codified procedures, or universal principles, Nonaka \& Takeuchi $(1995 ; 8)$.

The knowledge possessed by the company is a combination of tacit and explicit knowledge, therefore Knowledge Management is needed to capture all of these types of knowledge and then be used for the company's interests.

Table 1 - Classification of Knowledge Types

\begin{tabular}{|l|l|}
\hline \multicolumn{1}{|c|}{ Explicit Knowledge } & \multicolumn{1}{c|}{ Tacit Knowledge } \\
\hline Tangible & Intangible \\
\hline Physical objects such as documents, databases. & Mental objects such as thoughts, reasons. \\
\hline Does not depend on context & Context affects meaning \\
\hline Easy to share & Need efforts to express and share the knowledge \\
\hline Easy to reproduce & Not easy to replicate/imitate \\
\hline
\end{tabular}

Source: Khoe Yao Tung ( 2018; 50)

Knowledge management is all activities that include the process of finding, obtaining, making, sharing information or knowledge that is tacit and explicit, which then to be used for the benefit of the company to create an effective and efficient company and to be used as much as possible by its employees to improve their performance in achieving company goals and then that knowledge use is employed to achieve company goals. Sue Brelade \& Chris Harman (2003: 5) stated that knowledge management is the process of connecting the right people with the right information at the right time. According to Honeycutt (2005) there are several dimensions that can be used to measure knowledge management within a company, they are: Personal Knowledge; Job Procedures; Technology.

The human resource development for business enterprises is generally aimed at increasing employee productivity and making the company superior to its competitors. The development of human resources (HR) is more focused on training both formal and nonformal provided by companies or organizations for the purpose to develop the skills, knowledge, and abilities of employees. The company's HR development process begins with recruitment and continues as long as the HR works for the company. Harris and DeSimone (1998: 2) stated about human resource development: "Human resource development can be defined as a set of systematic and planned activities designed by an organization to provide its members with necessary skills to meet current and future job demands". Wayne R Mondy (2010) defined human resource development as a management effort that is carried out well and continuously in order to improve employee competency and organizational performance through HR training, education and development.

Employee Performance is the result or output produced by the employee and the output can be measured and assessed. Armstrong and Baron in Ma'aruf $(2016 ; 3)$ stated that performance is the result of work that has strong relationships with goals, organizational 
strategy, customer satisfaction, and economic contribution. Veitzal Rivai et.al (2016; 1) defined performance as a general term that is used for part or all of the actions or activities of an organization in a period with references to a number of standards such as past or projected costs, with the basis of efficiency, accountability or management accountability and the likes. Gomes $(2010 ; 142)$ argued that there are 8 (eight) variables that can be used to measure employee performance based on specific behavior, they are:

- Quantity of work, the number of jobs completed in a given period;

- Quality of work, the quality of work produced based on predetermined provisions;

- Job Knowledge, the knowledge the employees have about their work;

- Creativeness, the authenticity of the ideas that are created and carried out in solving problems that arise in the work;

- Cooperation, the ability to work with other people in the company;

- Dependability, can be trusted to complete the work;

- Initiative, enthusiasm in doing new jobs with more responsibilities;

- Personal Qualities, the qualities possessed as a person who include personality, leadership, and integrity.

\section{FRAMEWORK OF STUDY}

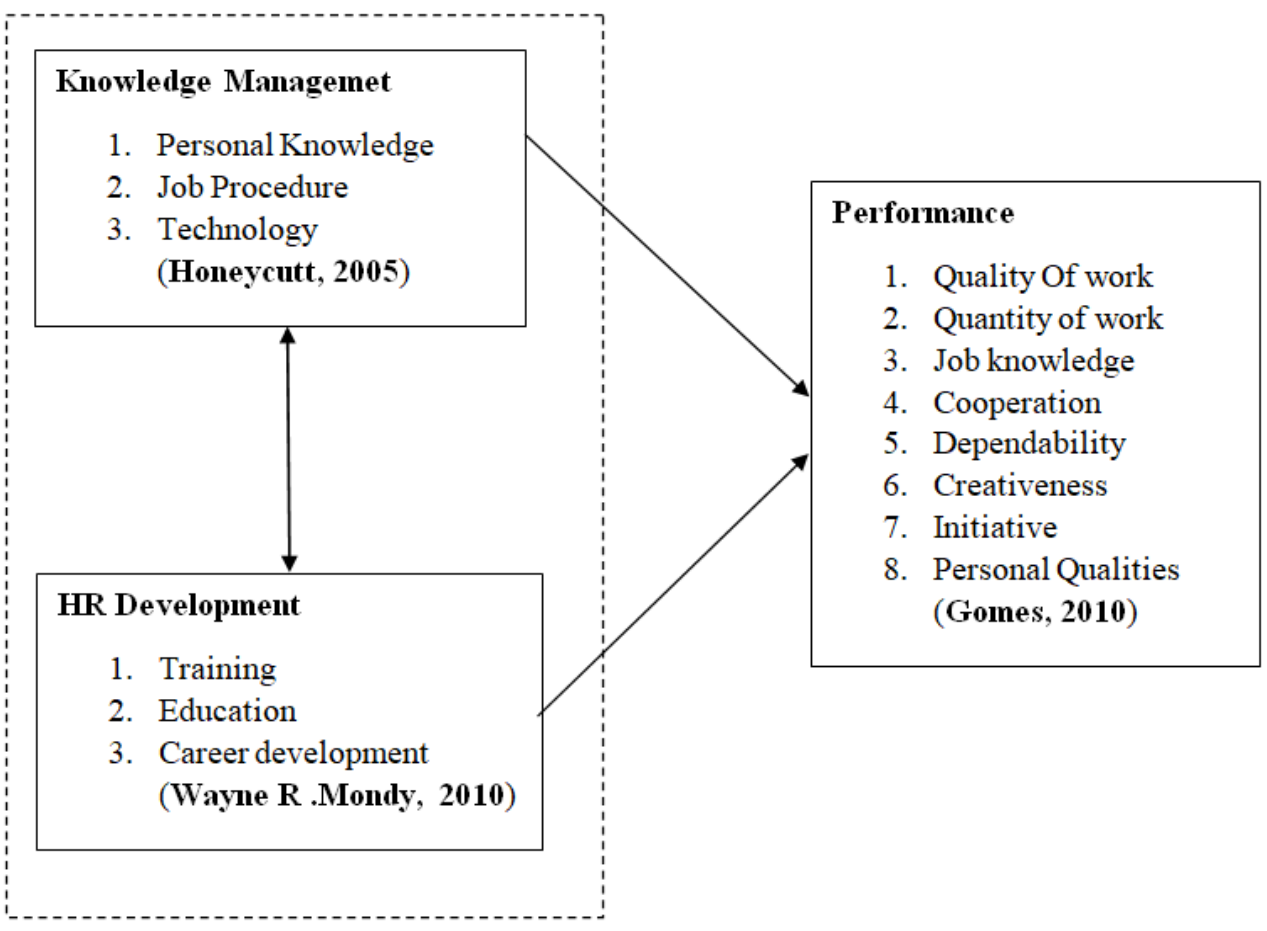

Figure 1 - Research paradigm

Khoe Yao Tung (2018: 103) described the benefits of knowledge management for developing human resources, including:

- Helping employees to keep up to date, this is because, with good knowledge management, the company can make its employees always have the latest knowledge that is useful for developing themselves as individuals;

- Measuring the value of knowledge assets, with knowledge management, the company can assess the knowledge assets owned by each of its employees so the company can determine the education and training programs needed by these employees;

- Helping each employee to carry out their work. Increased knowledge due to the application of knowledge management can make employees quickly adapt to their jobs; 
- Making the employees have fast and good decision-making and problem-solving;

- Providing a challenge to contribute to the company;

- Facilitating knowledge growth, through culture and incentives;

- Transferring existing knowledge, so that it can become the parts of the organization.

Gouzali in kadarisman (2012; 3) stated: The human resource development is an activity that must be carried out by organizations, so that their knowledge, abilities, and skills are in accordance with the demands of the work they do, the indicators of human resource development are training and education, these activities aim to increase knowledge and improve the skills of the participants, the material provided is explicit knowledge so that it can be easily delivered and learned by trainees.

The process of knowledge management includes the process of creation, dissemination through the transfer of knowledge, then the storage, and the last is the use and application of this knowledge into daily practice which can indirectly improve employee performance. Khoe Yao Tung $(2018 ; 3)$ revealed that knowledge management basically consists of a systematic process to obtain, organize, maintain, implement, share, and renew all forms of knowledge in order to improve organizational performance and to create value.

Performance is a record of production results in a job function that specifies activities for a certain period. It can be measured through 8 (eight) variables: Quantity of work, Quality of work, Job Knowledge, Cooperation, Dependability, Creativeness, Initiative, and Personal Qualities. (Gomes; 2010). A company requires cooperation from various stakeholders to be able to achieve its objectives, for which maximum performance is needed so that the goal is achieved. The performance of the company is very dependent on the performance of its Human Resources, therefore the efforts for human resource development are carried out to improve skills and increase knowledge of the HR, for the purpose of creating quality Human Resources. The aim of HR development is to increase the quantity and quality of output (Veithzal Rivai et.al 2015; 667). Quality human resources will certainly produce quality performance output as well

Based on the framework and literature review, the following hypotheses can be made:

- Knowledge management has a significant effect on the performance of employees at PT Sky Pacific Indonesia;

- Human Resource Development has a significant effect on the performance of employees at PT. Sky Pacific Indonesia;

- Knowledge management and Human Resource Development have a significant effect on the performance of employees at PT. Sky Pacific Indonesia.

\section{METHODS OF RESEARCH}

This study contains hypotheses that have a theoretical basis and procedures for compiling theories through deductive logic (Usman and Akbar 2003; 91). The hypothesis will be tested by path analysis (reason analyzer), with the reason to show and test the model of relationships between variables in the form of causality (not interactive / reciprocal relationships). Data obtained from questionnaire results as a basic data collection tool then processed using quantitative methods. Quantitative method is a process of finding knowledge that uses data in the form of numbers as a tool to analyze information about what you want to know (Kasiram 2008: 149).

The characteristics of the respondents consist of data on sex, age and type of work at PT. Sky Pacific Indonesia in Table 2.

Before the verification test with path analysis was carried out, the data normality test was first performed to determine whether the data were normally distributed or not. If the data were normally distributed, the verification analysis was done by the parametric method, but if the data were not normally distributed, the verification analysis was done by the nonparametric method. Using the help of the SPSS version 22.0 program application, the output of the following normality test results was obtained (Figure 2).

Table 2 - The Respondents' Sex 


\begin{tabular}{|c|c|c|}
\hline Sex & Total & Percentage \\
\hline Male & 44 & $71 \%$ \\
\hline Female & 18 & $29 \%$ \\
\hline Total & 62 & $100 \%$ \\
\hline
\end{tabular}

Table 3 - The Respondents' Age

\begin{tabular}{|c|c|c|}
\hline Age & Total & Percentage \\
\hline $21-30$ & 42 & $68 \%$ \\
\hline $31-40$ & 10 & $16 \%$ \\
\hline $41-50$ & 5 & $8 \%$ \\
\hline $50-57$ & 5 & $8 \%$ \\
\hline
\end{tabular}

Table 4 - The Respondents' type of work at PT. Sky Pacific Indonesia

\begin{tabular}{|l|l|l|}
\hline \multicolumn{1}{|c|}{ Type of work } & \multicolumn{1}{|c|}{ Total } & \multicolumn{1}{c|}{ Percentage } \\
\hline Leader (Director and Manager) & 9 & $15 \%$ \\
\hline Laboratory (Advisor, Supervisor, lab tech and analyst) & 18 & $29 \%$ \\
\hline Technician and Sampling Officer & 31 & $50 \%$ \\
\hline Administrative staff & 4 & $6 \%$ \\
\hline \multicolumn{1}{|c|}{ Total } & 62 & $100 \%$ \\
\hline
\end{tabular}

One-Sample Kolmogorov-Smirnov Test

\begin{tabular}{|ll|r|}
\hline & & $\begin{array}{c}\text { Unstandardized } \\
\text { Residual }\end{array}$ \\
\hline N & & 62 \\
Normal Parameters & ,b & Mean \\
Most Extreme & Std. Deviation &, 0000000 \\
Differences & Absolute & 6,30493158 \\
& Positive &, 112 \\
Kolmogorov-Smirnov Z & Negative &, 070 \\
Asymp. Sig. (2-tailed) & &,- 112 \\
\hline
\end{tabular}

a. Test distribution is Normal.

b. Calculated from data.

Figure 2 - Normality Test Results

Based on the SPSS output above, the normality test Sig. value was obtained using the Kolmogorov-Smirnov method by 0.413 . Because the value of the $p$-value was greater than alpha $(0.413>0.05)$, it can be concluded that the data were normally distributed, so that the verification analysis was done by the parametric method of path analysis.

Based on the research instrument testing that had been conducted, it was found that all statement items had a validity coefficient (pearson product moment) greater than $r$-critical 0.3 , and each variable had a reliability coefficient (Alpha-Cronbach) greater than 0,7 . So, the items in the questionnaire were valid and reliable in measuring the variables.

\section{RESULTS AND DISCUSSION}

In knowledge management variable with 20 items of statements and 62 people of respondents, a total score of 5176 was obtained. So that the description of knowledge management obtained is as follows.

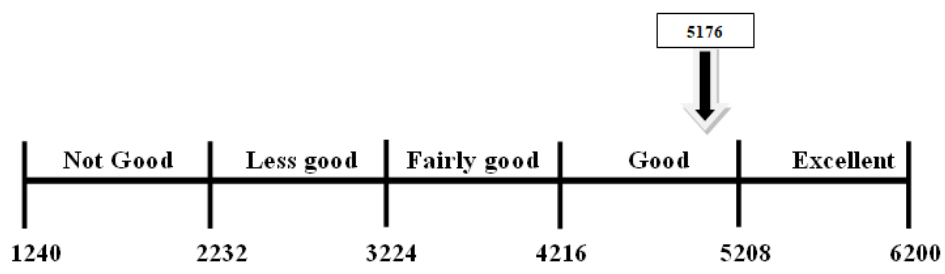


Based on the continuum line about knowledge management, it can be seen that the respondent's response to knowledge management at PT.Sky Pacific Indonesia was considered good.

On the human resource development variable with 14 items of statements and 62 people of respondents, a total score of 3767 was obtained. So that the description of the

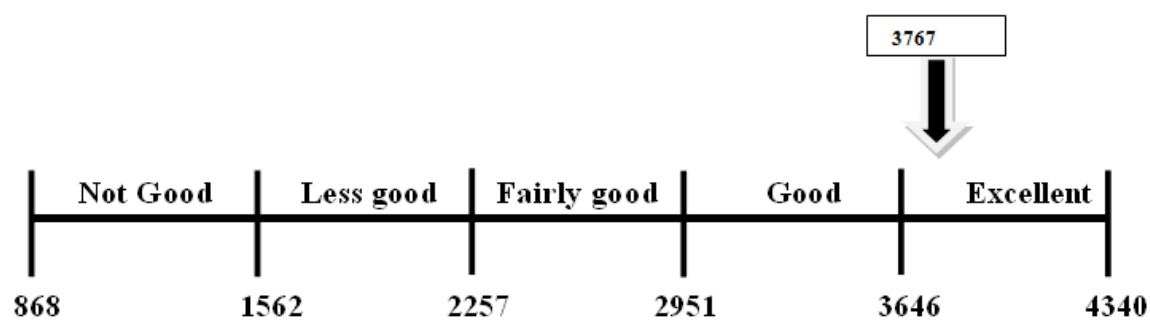

Based on the continuum line on human resource development, it can be seen that the respondent's response to human resource development at PT.Sky Pacific Indonesia was considered excellent.

On the employee performance variable with 17 items of statements and 62 people of respondents, a total score of 4581 was obtained. So that the description of the employee performance obtained is as follows.

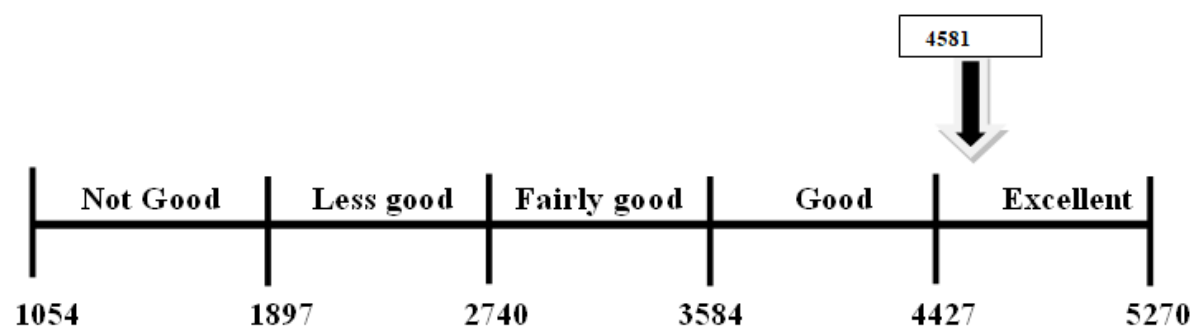

Based on the continuum line about employee performance, it can be seen that the respondent's response about the performance of employees at PT.Sky Pacific Indonesia was considered excellent.

Verification analysis is an analysis of model and evidence to find the truth from the hypotheses proposed. In this study, verification analysis aimed to find out the results of the research related to the effect of knowledge management and human resource development on employee performance at PT. Sky Pacific Indonesia. The method used in this verification analysis was path analysis. Before the verification test with path analysis was carried out, the normality test was done first using the Kolmogorov-Smirnov method with the purpose to find out whether the data were normally distributed or not. The $\mathrm{p}$-value obtained from the normality test was greater than alpha $(0.413>0.05)$, it can be concluded that the data were normally distributed, so path analysis could be conducted.

Below is the path equation in this study:

$$
Y=\rho_{y \times 1} X_{1}+\rho_{y \times 2} X_{2}+\varepsilon
$$

Where: $X_{1}=$ knowledge management; $X_{2}=$ human resource development; $Y=$ employee performance. follows:

Based on the results of calculations with path analysis, the path equation obtained is as

$$
Y=0,296^{*} X_{1}+0,519^{*} X_{2}
$$




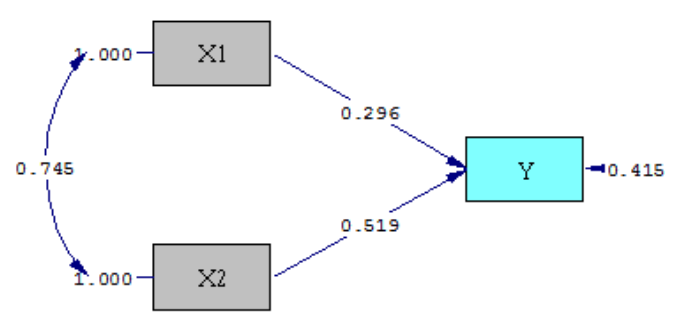

Figure 3 - The Path Chart of The Effect of Knowledge Management and Human Resource Development to Employee Performance

The table that shows the results of the first hypothesis testing is presented below:

Table 5 - Test results of The Relationship of Knowledge Management and Human Resource Development

\begin{tabular}{|c|c|c|c|c|c|}
\hline Correlation coefficient & $\mathrm{T}_{\text {count }}$ & $\mathrm{t}_{\text {table }}(\mathrm{db}: 60)$ & $p$-value & $\mathrm{H}_{0}$ & $\mathrm{H}_{1}$ \\
\hline 0.745 & 8.651 & 2,000 & 0,000 & Rejected & Accepted \\
\hline
\end{tabular}

Based on the test results in the table above, it can be seen that the $t_{\text {count }}$ value obtained was 8,651 and the $p$-value was 0,000 . Because $t_{\text {count }}(8,651)>t_{\text {table }}(2,000)$ and $p$-value $(0,000)<0,05$ then it was decided that $\mathrm{H}_{0}$ was rejected and $\mathrm{H}_{1}$ was accepted. Therefore, there is a significant relationship between knowledge management and human resource development.

The table that shows the results of the second hypothesis testing is presented below:

Table 6 - Test results of The Effect of Knowledge Management on Employee Performance

\begin{tabular}{|c|c|c|c|c|c|}
\hline Path coefficient & $t_{\text {count }}$ & ttable $(\mathrm{db}: 59)$ & $p$-value & $\mathrm{H}_{0}$ & $\mathrm{H}_{1}$ \\
\hline 0,296 & 2,350 & 2,001 & 0,022 & Rejected & Accepted \\
\hline
\end{tabular}

Based on the test results in the table above, it can be seen that the $t_{\text {count }}$ value of knowledge management variable was 2,350 and the $p$-value was 0,022 . Because $t_{\text {count }} 2,350$ $>t_{\text {table }} 2,001$ and $p$-value $(0,022)<0,05$ then it was decided that $\mathrm{H}_{0}$ was rejected and $\mathrm{H}_{1}$ was accepted. Therefore, knowledge management has a significant effect on employee performance.

The table that shows the results of the third hypothesis testing is presented below:

Table 7 - Test results of The Effect of Human Resource Development on Employee Performance

\begin{tabular}{|c|c|c|c|c|c|}
\hline Path coefficient & $\mathrm{t}_{\text {count }}$ & $\mathrm{t}_{\text {table }}(\mathrm{db}: 59)$ & $p$-value & $\mathrm{H}_{0}$ & $\mathrm{H}_{1}$ \\
\hline 0,519 & 4,124 & 2,001 & 0,000 & Rejected & Accepted \\
\hline
\end{tabular}

Based on the test results in the table above, it can be seen that the $t_{\text {count }}$ value of Human Resource Development variable was 4,124 and the $p$-value was 0,000 . Because $t_{\text {count }}$ $4,124>t_{\text {table }} 2,001$ and $p$-value $(0,000)<0,05$ then it was decided that $H_{0}$ was rejected and $\mathrm{H}_{1}$ was accepted. Therefore, Human Resource Development has a significant effect on employee performance.

The table that shows the results of the fourth hypothesis testing is presented below:

Table 8 - Test results of The Effect of Knowledge Management and Human Resource Development on Employee Performance

\begin{tabular}{|c|c|c|c|c|}
\hline$F_{\text {count }}$ & Ftable $(\mathrm{db}: 59)$ & $p$-value & $\mathrm{H}_{0}$ & $\mathrm{H}_{1}$ \\
\hline 41,521 & 3,153 & 0,000 & Rejected & Accepted \\
\hline
\end{tabular}

Based on the test results in the table above, it can be seen that the $F_{\text {count }}$ value was 41,521 and the $p$-value was 0,000 . Because $F_{\text {count }} 41,521>F_{\text {table }} 3,153$ and $p$-value $(0,000)<$ 0,05 then it was decided that $\mathrm{H}_{0}$ was rejected and $\mathrm{H}_{1}$ was accepted. Therefore, Knowledge 
Management and Human Resource Development have a significant effect on employee performance.

\section{CONCLUSION} follows:

After analysis and discussion in the previous chapter, conclusions can be taken as

1. Knowledge management has a significant effect on employee performance at PT.Sky Pacific Indonesia, with a direct influence of $8.76 \%$, and indirect effects through Human Resource Development by $11.44 \%$. Furthermore, the total influence of Knowledge Management on Employee Performance is $20.20 \%$, it means that $20.20 \%$ of changes in the performance of employees of PT Pacific Pacific Indonesia are influenced by Knowledge Management.

2. Development of human resources has a significant effect on the performance of employees at PT.Sky Pacific Indonesia, with a direct influence of $26.94 \%$, and indirect influence through Knowledge Management of $11.44 \%$. Furthermore, the total influence of Knowledge Management on Employee Performance is $38.38 \%$, meaning that $38.38 \%$ of the changes that occur in the performance of employees of PT Pacific Pacific Indonesia are influenced by the application of Human Resource Development.

3. Knowledge management and human resource development have a significant effect on the performance of employees at PT.Sky Pacific Indonesia, with a total influence of $58.58 \%$, while the rest or other variables not examined that affect Employee Performance are $41.42 \%$. this means that $58.58 \%$ improvement on employee performance at PT. Sky Pacific Indonesia can be explained by Knowledge Management and Human Resource Development variables, while the remaining $41.42 \%$ is influenced by other factors not examined.

\section{REFERENCES}

1. Alavi, M. and Leider,D. 2001. Knowledge Management and Knowledge Management Systems: Conceptual foundations and research issues. MIS Quarterly, Vol. 25, No. 1 pp. 107-136.

2. Azwar S. 2010. Reliabilitas and Validitas. Yogyakarta: Pustaka Pelajar.

3. DeSimone R.L \& Harris D.M. 1998. Human Resources Development; $2^{\text {nd }}$ edition. Orlando; the Dryden Press. pp. 2.

4. Frappaolo.C and Wayne, Tom. 1997. Knowledge Management: Form Terra Incognita to Terra Firma. Delphigroup.com. pp.12.

5. Ghozali, Imam. 2011. Aplikasi Multivariate dengan program IBM SPSS. Semarang: Badan Penerbit Universitas Diponegoro.

6. Gomes, C. Faustino 2010, Manajemen Sumber Daya Manusia. Yogyakarta Andi Offset. pp.142.

7. Harun Al Rasyid. 1993. Metoda sampling and Penskalaan, Jurusan Statistika Universitas

8. Padjadajaran.

9. Honeycutt, J. 2005. Knowledge management strategies; Strategi manajemen pengetahuan. Jakarta: PT. Elex Media Komputindo

10. Ikujiro Nonaka \& Hirotaka Takeuchi. 1995. The Knowledge Creating Company. New York; Oxford University Press. pp.8.

11. Kimiz Dalkir. 2011. Knowledge Management in Theory and Practice. Massachusetts Institute of Technology. Stone Sans and Stone by Toppan Best-set Premedia Limited.

12. Khoe Yao Tung. 2018. Memahami Knowledge Management. Pt. Indeks. Jakarta. pp. 50

13. Kusnendi. 2008. Model-model Persamaan Struktural. Bandung: Alfabeta.

14. Ma'aruf Abdullah. 2016. Manajemen and Evaluasi Kinerja Karyawan. Aswaja Pressindo. Yogyakarta. pp.3.

15. Mondy, R. Wayne. 2010. Human Resource Management. Eleventh Edition. New Jersey: Pearson. Education, Inc. 
16. Singarimbun, Masri. 1995. Metode Penelitian Survey. LP3S. Jakarta.

17. Soekidjo Notoatmodjo 2015. Pengembangan Sumber Daya Manusia. Jakarta, PT Rineka Cipta. pp. 139

18. Sue Brelade and Chiss Harman. 2003. A Practical Guide To Knowledge Management. London Thorogood. pp.5.

19. Sudjana. 2005. Metoda Statistika. Tarsito. Bandung.

20. Sugiyono. 2011. Metode Penelitian Kuantitatif and Kualitatif and R\&D. Bandung. CV. Alfabeta.

21. Sugiyono. 2013. Metode Penelitian Bisnis. Bandung.CV.Alfabeta.

22. Thembile Moses Manele, 2005: Knowledge Creation and Transfer: Implications for Knowledge.

23. Management in Parliamentary Service: Thesis: University of Stellenbosch: South Africa. pp.1.

24. Ulber, S. 2009. Metode Penelitian Sosial. Bandung: PT Refika Aditama.

25. Usman, Hundaeni and P.S Akbar. 2003. Metodologi Penelitian Sosial. Jakarta. Bumi Aksara.

26. Veithzal Rivai Zainal, Yunswar Zainul Basri, Itjang D.Gunawan, and Gatot Mardiwasito. 2015. Manajemen Kinerja: Yogyakarta. pp.1. 